\section{Federation University ResearchOnline}

\section{https://researchonline.federation.edu.au}

Copyright Notice

This is the published version of:

Sandhu, H., Müller, A., Sukhdev, P., Merrigan, K., Tenkouano, A., Kumar, P., Hussain, S., Zhang, W., Pengue, W., Gemmill-Herren, B., Hamm, M. W., Tirado von der Pahlen, M. C., Obst, C., Sharma, K., Gundimeda, H., Markandya, A., May, P., Platais, G., \& Weigelt, J. (2019). The future of agriculture and food: Evaluating the holistic costs and benefits. The Anthropocene Review, 6(3), 270-278.

Available online: https://doi.org/10.1177/2053019619872808

Copyright (C) The Authors 2019. This is an Open Access article distributed under the terms of the Creative Commons Attribution-Non Commercial 4.0 International License (http://creativecommons.org/licenses/by-nc/4.0/), which permits others to distribute, remix, adapt, build upon this work non-commercially, and license their derivative works on different terms, provided the original work is cited and the use is non-commercial. Commercial use is not permitted. 


\title{
The future of agriculture and food: Evaluating the holistic costs and benefits
}

The Anthropocene Review 2019, Vol. 6(3) 270-278

(C) The Author(s) 2019 Article reuse guidelines: sagepub.com/journals-permissions DOI: $10.1177 / 2053019619872808$ journals.sagepub.com/home/anr

@SAGE

\author{
Harpinder Sandhu, ${ }^{1,2}$ (D) Alexander Müller, ${ }^{3}$ \\ Pavan Sukhdev, 4,8 Kathleen Merrigan, ${ }^{5}$ \\ Abdou Tenkouano, ${ }^{6}$ Pushpam Kumar, ${ }^{7}$ \\ Salman Hussain, ${ }^{8}$ Wei Zhang, ${ }^{9}$ Walter Pengue, ${ }^{10}$ \\ Barbara Gemmill-Herren, 1 Michael W Hamm, ${ }^{12}$ \\ Maria Cristina Tirado von der Pahlen, ${ }^{13}$ Carl Obst, ${ }^{14}$ \\ Kavita Sharma, ${ }^{8}$ Haripriya Gundimeda, ${ }^{15}$ Anil Markandya, ${ }^{16}$ \\ Peter May, ${ }^{17}$ Gunars Platais ${ }^{18}$ and Jes Weigelt ${ }^{3}$
}

\begin{abstract}
Inadequacies of the current agriculture and food systems are recognised globally in the form of damages to environment and human health. In addition, the prevailing economic and policy systems do not reflect these damages in its accounting systems and standards. These shortcomings lead to perverse and pervasive outcomes for society at large. Our proposal is to consider all social and environmental externalities - both negative and positive, in global agriculture and food systems and reflect them in an economic system by evaluating comprehensive costs and benefits. This can be done by adopting an innovative, universal, and inclusive framework (the 'TEEBAgriFood' framework) in order to stimulate appropriate policy responses.
\end{abstract}

\section{Keywords}

externalities, human capital, natural capital, social capital, sustainable agriculture, TEEB

\footnotetext{
'University of South Australia, Australia

${ }^{2}$ Flinders University, Australia

3TMG - Töpfer, Müller, Gaßner - Think Tank for

Sustainability, Germany

${ }^{4}$ GIST Advisory, India

${ }^{5}$ Arizona State University, USA

${ }^{6}$ West and Central African Council for Agricultural

Research and Development, Senegal

7UN Environment, Kenya

\&UN Environment, Switzerland

International Food Policy Research Institute, USA

10National University of General Sarmiento and University

of Buenos Aires, Argentina

"World Agroforestry Centre, Kenya
}

\author{
12Michigan State University, USA \\ ${ }^{13}$ Loyola Marymount University, USA \\ ${ }^{14}$ Institute for Development of Environmental-Economic \\ Accounting and University of Melbourne, Australia \\ ${ }^{15}$ Indian Institute of Technology, Bombay, India \\ ${ }^{16}$ BC3 Basque Centre for Climate Change, Spain \\ ${ }^{17}$ Federal Rural University of Rio de Janeiro, Brazil \\ 18World Bank, USA
}

Corresponding author:

Harpinder Sandhu, School of Natural and Built Environments, University of South Australia, GPO Box 247I, Adelaide, SA 500I, Australia.

Email: Harpinder.sandhu@unisa.edu.au 
Agriculture worldwide is under immense pressure to simultaneously produce enough healthy food for a growing population while minimising impacts on environment and human health, which have begun to pose increasing risks to ecosystems and society (Sukhdev, 2018; UNEP, 2016). There is thus acute need to understand the complex interdependencies and impacts of agriculture on ecosystems and economy. Globally, scientific literature in the last two decades has provided robust understanding to capture the value of natural capital, especially contribution of ecosystem services to human well-being (Daily, 1997; Costanza et al., 1997, 2014, 2017; Millennium Ecosystem Assessment (MEA), 2005; Pascual et al., 2017; The Economics of Ecosystems and Biodiversity (TEEB), 2008) and to study socioeconomic and environmental sustainability through the Coupled Human and Natural Systems (CHANS; Liu et al., 2007a, 2007b) and the telecoupling framework (Adger et al., 2009; Liu et al., 2013, 2015). These theoretical underpinnings have become the basis for several initiatives such as the Wealth Accounting and the Valuation of Ecosystem Services (WAVES) to account for natural resources into development planning led by the World Bank, the Economics of Land Degradation (ELD) initiative to understand the ELD and benefits of land and land-based ecosystems (Von Braun et al., 2013), and the Natural Capital Coalition to support business community to incorporate ecosystem services and their values into their operations (https:// naturalcapitalcoalition.org/). However, agriculture and food sector that covers about 5 billion hectares of global surface area and contributes USD3.4 trillion to the global economy annually has not been addressed in a comprehensive manner by such global initiatives. Moreover, a quarter of the global greenhouse emissions are linked to agriculture and land use changes, and other damages arising from agriculture and the food sector are often denied or invisible to economic actors and consumers, thus impeding their being effectively addressed by public policies (TEEB, 2015). Recognising its significance, the United Nations (UN) Environment's initiative the Economics of Ecosystems and Biodiversity for Agriculture and Food (TEEBAgriFood; TEEB, 2018) has been seeking to understand the hidden links among agriculture, ecosystems and society in pursuit of making appropriate and effective policy response (Sandhu et al., 2019). It builds on the existing scientific literature and understanding of natural, social and human capital, for human well-being. Its main goal is to analyse the current 'eco-agri-food' systems holistically by using an innovative lens that addresses social and environmental concerns and reflects them in an economic and social context by evaluating the extent of otherwise unaccounted costs and benefits.

\section{The current approach}

'Eco-agri-food' systems is a collective term encompassing the vast and interacting complex of ecosystems, agricultural lands, pastures, fisheries, labour, infrastructure, technology, policies, culture, traditions, and institutions (including markets and local knowledge) that are variously involved in growing, processing, distributing, and consuming food (TEEB, 2015, 2018). The current approach that evaluates agriculture and food systems is able to perceive only a part of this complex system. It recognises that agricultural production is dependent on labour, machinery, technology, and inputs such as fertilisers and pesticides. These critical inputs are considered to be 'visible' in the sense that their value to agricultural systems is accounted for and reflected in decision-making at all levels (farm, industry, national and international policy). The market value of food reflects these costs but often ignores other elements of the total cost of inputs, especially those derived 'free' from nature. These include nutrient cycling, pollination and biological pest control. Such inputs are known as ecosystem services and are positive externalities in agriculture systems (Dominati et al., 2010; Power, 2010; Sandhu et al., 2016; Swinton et al., 2007; Zhang et al., 2007). Despite their immense value, the clear benefits they provide are not typically accounted for in market transactions and remain 'invisible', in economic terms (International Panel of Experts on 
Sustainable Food Systems (IPES-Food), 2016; TEEB, 2015, 2018). Negative externalities such as nutrient run-offs, losses of biodiversity, generation of greenhouse gas emissions and wastage in the entire value chain of food systems are also not captured by economic systems. Therefore, society and the economy are unable to see either the positive or negative impacts associated with agriculture and food systems.

The invisibility of large impacts and dependencies on mainstream agricultural models has become entrenched through excessive focus on 'sector' silos and 'per-hectare productivity' as the indicator of choice (TEEB, 2018). For example, agronomists may have a clear goal of improving productivity and are also aware of certain negative externalities and interdependencies on nature. However, these interconnections and dependencies are not adequately addressed in evaluations and broader policy discussions. There is limited practice of carrying out the full cost and benefits of any impacts of agronomic practices on natural, social, and human capital, let alone through the entire value chain (inputs, processing, consumption and post consumption stages). In addition, the current regulations and legislations are also focused only on limited negative externalities such as European Union legislation on nitrates for reducing water pollution from agricultural sources (Council of the European Union, 1991). Despite having sustainable use of natural resources as one of the three objectives of the Common Agricultural Policy (CAP) of Europe, there is less focus on including all invisible costs and benefits in the Common Monitoring and Evaluation Framework of the CAP (European Commission, 2018). The current approach allows only partial analysis, where significant externalities associated with many inputs and outputs to manufacturing and farming are not considered in making decisions about the adoption of such agronomic practices.

There are scientists, practitioners, farmers and policy makers, who recognise various externalities, but means of making these 'visible' is constrained due to the limitations of the current tools and approaches. Hence, the TEEBAgriFood evaluation framework has been developed to identify the types and magnitudes of such costs and benefits, which can in turn initiate appropriate policy responses (Sandhu et al., 2019).

\section{The evaluation framework}

The TEEBAgriFood study has been a collective effort of about 150 experts from around the world using a transdisciplinary approach including disciplines such as agronomy, agroecology, environmental economics, health science, nutrition, social science, accounting, law, ethics, and political economy. The framework is universal (applicable to any geographical, ecological, or social context), comprehensive (includes all impacts or dependencies along the food value chain) and inclusive (supports multiple approaches to assessment). Its central tenet is that agriculture and food systems should be investigated holistically (Figure 1). This lens allows us to identify and value natural capital (e.g. well-functioning biodiversity and ecosystems), human capital (e.g. skills and knowledge), produced capital (e.g. finance and machinery) and social capital (e.g. societal interactions, relationships, formal and informal institutions) associated with agriculture and food systems. It also helps identify the impacts of diverse agriculture and food systems on natural, human, and social capital stocks, which comprise the most significant parts of the wealth of nations (World Bank, 2006).

With this lens, the 'eco-agri-food' systems can be investigated and transformed. The outcomes of this investigation can enable decision makers at farm, business, and policy level to (1) identify various externalities associated with different production systems, distribution of food- or wasterelated impacts; (2) provide information to agriculture and food businesses about options available to account for and internalise the value of environmental externalities and natural capital in their 


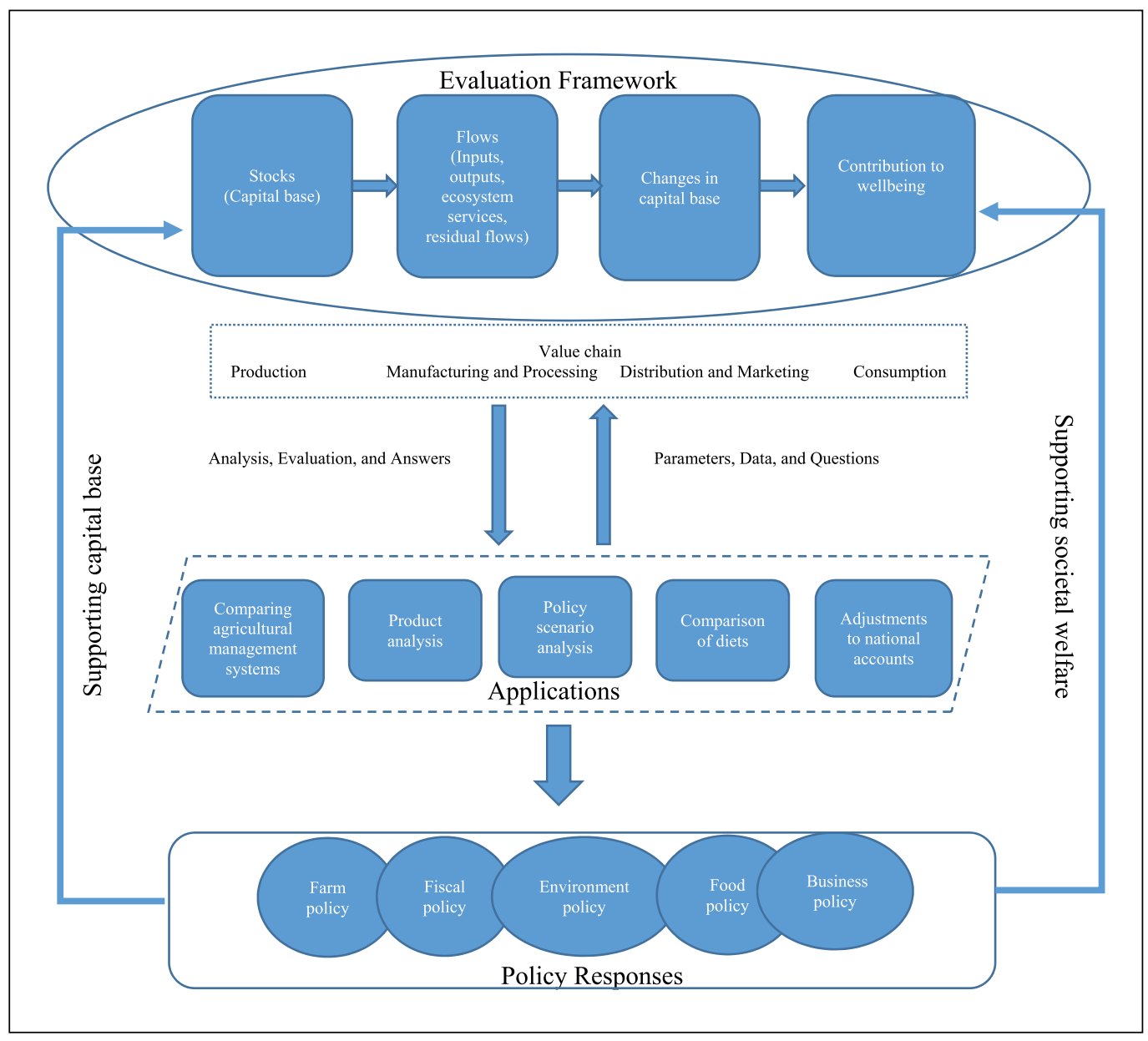

Figure I. TEEBAgrifood evaluation framework comprises stocks, flows, outcomes and impacts. These four elements capture various interactions in the 'eco-agri-food' systems complex. The stocks comprise four different capitals - produced capital, natural capital, human capital and social capital. These stocks underpin a variety of flows encompassing production and consumption activity, ecosystem services, purchased inputs and residual flows such as pollution and greenhouse gas emissions. The dynamics of an 'ecoagri-food' system lead to outcomes that are reflected as changes in the stocks of capitals. In turn, these outcomes determine the impacts on socioeconomic, health and environmental well-being. The framework is designed for five wide ranging kinds (or families) of applications through the entire value chain. Each kind of application provides a set of data and questions which can be reflected by the analysis using the framework to help derive a coherent policy response. Policy responses can in turn support the capital base of agriculture and food systems and improve societal well-being.

businesses and in consumer awareness and (3) contextualise agricultural systems in economic and environmental policy to highlight the values generated by all types of farming systems for employment, food and ecological security. This can catalyse fruitful links among the dimensions of the 'eco-agri-food' systems for sustainable agriculture development and can effectively contribute towards the achievement of UN Sustainable Development Goals (SDGs; UN, 2015). 


\section{Application for policy responses}

TEEBAgriFood's framework is being developed to look beyond the obvious and estimate costs and benefits in agriculture and food systems by considering all stages of the value chain including consumption and disposal of waste. This can help develop an appropriate policy response to correct inequities and negative externalities in agriculture and food systems. For example, when the magnitude of global food wastage and its associated social and environmental costs were not known, it was not on the policy agenda around the world. But due to recent global efforts, now it is known that approximately one-third of all food is lost or wasted and that it costs about USD1 trillion each year to the economy (Food and Agriculture Organization (FAO), 2014a). This has now become a focus of policymakers and practitioners around the world through Goal 12 of the SDGs (Target 12.3), which aims to reduce food wastage to half by 2030 (UN, 2015). However, the full environmental and social costs of food waste have not been calculated in a comprehensive way.

Similarly, this unique, innovative, comprehensive and inclusive TEEBAgriFood framework will help recognise and accelerate responses through various applications at field, business, and country level. The framework is designed to be used as a common 'wide-angle' lens for applications as diverse as (1) comparisons of different agricultural management systems (e.g. organic, conventional, natural farming, high- or low-input systems), (2) comparisons of the true costs and benefits of alternative food products (e.g. grass-fed beef versus grain-fed beef), (3) dietary comparisons (e.g. Mediterranean diet, plant based diet, vegetarian diet), (4) policy scenario analyses (e.g. farm and agricultural related public or private sector policies), and (5) to derive adjustments to the accounts (e.g. standard national accounts and adjusted national accounts after internalising externalities; Figure 1).

Application of the framework is a process that includes defining purpose of the evaluation, describing scope of the value chain, evaluating all stocks, flows, of four capitals and determining the social, economic and environmental impacts on the society (Obst and Sharma, 2018). As an application of the framework, we highlight one example from the suggested five types of applications, comparison of food products (grass-fed vs grain-fed beef). Grain-fed beef production is associated with large number of negative externalities as compared to the grass-fed beef production systems. Such studies do not capture all elements of the framework as highlighted by this example (Table 1). For example, residual flows, waste generated in all stages of value chains and impacts on human and social capital are not described or monetised (Sandhu et al., 2018). Such comparisons can be more useful for consumers and business organisations if they include information about social, health and all environmental costs throughout the value chain. A TEEBAgriFood-type analysis can examine all negative and positive externalities of beef production systems, including health concerns over antibiotic resistance, worker safety, animal welfare, impacts on local and often low-income communities and healthy diets. In addition, it is not possible to make policy decisions that promote specific outcomes on any one of these concerns without having impacts on others. Therefore, the comparison of two systems can utilise systems model for which the impacts of different policy interventions could be played out. For example, a complete assessment of the implication of single-policy measures, such as banning antibiotic use in beef production or removing subsidies for animal feedstocks, would give policy makers the ability to perceive 'ripple effects' on other parts of the food system. Framework can be used to evaluate the value, throughout the food chain (thus for producers, but also communities living near processing plants, and consumers) of alternative, low-impact ways of creating agricultural products. 
Table I. Various elements of the evaluation framework covered in the beef study are shown by shaded cells (Sandhu et al., 20I8).

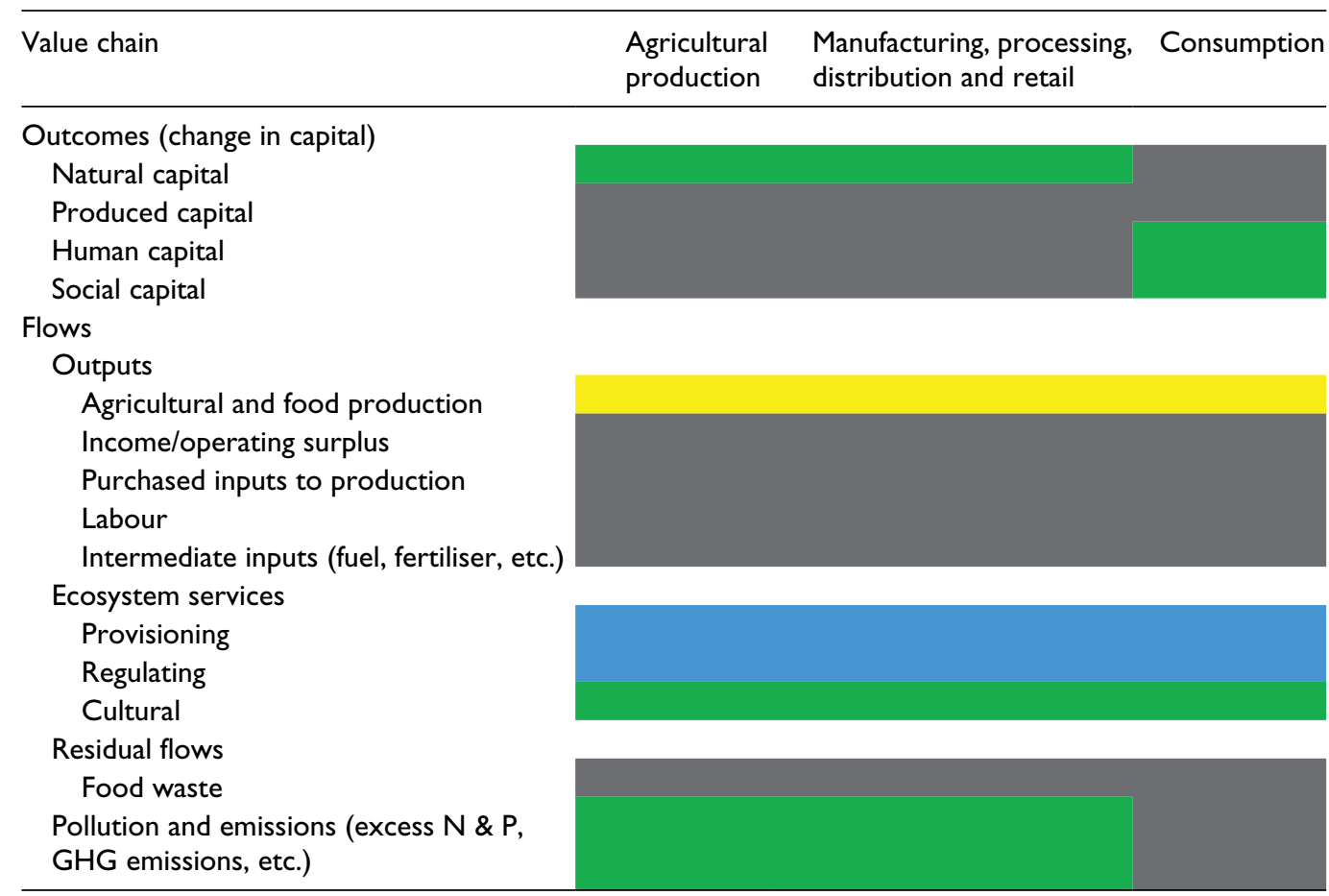

GHG: greenhouse gas.

\begin{tabular}{|l|l|}
\hline Legend & \\
\hline & Descriptive information available \\
\hline & Quantitative information available \\
\hline & Monetised information available \\
\hline & Not included in study \\
\hline
\end{tabular}

\section{Conclusion}

There are a number of potential uses of this framework: in evaluating agricultural and food, health and environmental policies at government level; comparing different food and beverage products for business; and comparing different production systems at farm level. For example, one potential example is about health impacts from exposure to agrochemicals (Forouzanfar et al., 2015; Tilman and Clark, 2014; Trasande et al., 2015). In the European Union, pesticide exposure causes annual health and economic costs at about USD127 billion, almost four times as high as the second highest category (plastics; Trasande et al., 2015). Current evaluations of agricultural policies do not consider these agriculture and food system systemic impacts. Hence, we often fail to consider links such as those between pesticide use (often supported by large subsidies) and the rising costs of health care in a country, let alone their impact on biodiversity, natural resources and environmental justice. 
Another potential use is at farm level, where 500 million family farms are recognised globally (FAO, 2014b) and farming employs one-quarter of the globally employed population (ILOSTAT, 2018). However, there is less emphasis on valuing this key component of the agriculture sector in national and global policies. The framework can help evaluate the socioeconomic dependence of large numbers of rural dwellers on the farming sector so that these contributions can be valued as an integral part of the economic systems and be duly rewarded by society.

The TEEBAgriFood framework builds on the existing robust scientific underpinnings and extends them to provide a way forward for the global agriculture community to evaluate the current and future 'eco-agri-food' systems. This will help to develop new impetus and modify current agriculture and food systems, so that they can be equitable, deliver the required amount of food, meet calorific and nutritional requirements of all, minimise waste, protect biodiversity and ecosystem services and reduce climate risks. TEEBAgriFood intends to build a consensus among citizens, farmers, businesses, policy makers and other decision makers by recommending an innovative lens that acknowledges, integrates and reflects linkages between agriculture, environment and society. It is a novel step in the direction to evaluate the true costs and benefits of 'eco-agri-food' systems by using a transdisciplinary approach. We see this not as an end point, but a beginning, as scholars build upon this work and improve the valuation of externalities. We believe it has potential to stimulate policy shifts to identify and correct the inadequacies of agriculture and food systems in numerous countries around the world. It could be particularly effective if it is used by countries and by transnational initiatives (such as the European Union's CAP), to evaluate choices from the perspective of achieving the SDGs, which are all strongly dependent on achieving truly healthy and equitable agricultural and food systems.

\section{Declaration of conflicting interests}

The author(s) declared no potential conflicts of interest with respect to the research, authorship and/or publication of this article.

\section{Funding}

The authors disclosed receipt of the following financial support for the research, authorship, and/or publication of this article: The TEEBAgriFood study is funded by the Global Alliance for the Future of Food, European Commission, and the Government of Norway.

\section{ORCID iD}

Harpinder Sandhu (iD https://orcid.org/0000-0001-5428-094X

\section{References}

Adger WN, Eakin H and Winkels A (2009) Nested and teleconnected vulnerabilities to environmental change. Frontiers in Ecology and the Environment 7: 150-157.

Costanza R, d'Arge R, de Groot R et al. (1997) The value of the world's ecosystem services and natural capital. Nature 387: 253-260.

Costanza R, de Groot R, Braat L et al. (2017) Twenty years of ecosystem services: How far have we come and how far do we still need to go? Ecosystem Services 28: 1-16.

Costanza R, de Groot R, Sutton PC et al. (2014) Changes in the global value of ecosystem services. Global Environmental Change 26: 152-158.

Council of the European Union (1991) Council Directive 91/676/EEC of 12 December 1991 Concerning the Protection of Waters against Pollution Caused by Nitrates from Agricultural Sources. Brussels: Council of the European Union. 
Daily GC (1997) Nature's Services: Societal Dependence on Natural Ecosystems. Washington, DC: Island Press.

Dominati E, Patterson M and Mackay A (2010) A framework for classifying and quantifying the natural capital and ecosystem services of soils. Ecological Economics 69: 1858-1868.

European Commission (2018) Report on the implementation of the Common Monitoring and Evaluation Framework and first results on the performance of the Common Agricultural Policy. Report from the Commission to the European Parliament and the Council. Available at: https://ec.europa.eu/info/foodfarming-fisheries/key-policies/common-agricultural-policy/cap-glance/cmef_en

Food and Agriculture Organization (FAO) (2014a) Food Wastage Footprint: Full-Cost Accounting. Rome: FAO.

Food and Agriculture Organization (FAO) (2014b) The State of Food and Agriculture 2014: Innovation in Family Farming. Rome: FAO.

Forouzanfar MH, Alexander L, Anderson HR et al. (2015) Global, regional, and national comparative risk assessment of 79 behavioural, environmental and occupational, and metabolic risks or clusters of risks in 188 countries, 1990-2013: A systematic analysis for the Global Burden of Disease Study 2013. The Lancet 386: 2287-2323.

ILOSTAT (2018) Geneva: International Labour Organization. Available at: https://www.ilo.org/ilostat

International Panel of Experts on Sustainable Food Systems (IPES-Food) (2016) From Uniformity to Diversity: A Paradigm Shift from Industrial Agriculture to Diversified Agroecological Systems. Louvain-la-Neuve: IPES-Food.

Liu J, Dietz T, Carpenter SR et al. (2007a) Coupled human and natural systems. AMBIO: A Journal of the Human Environment 36: 639-649.

Liu J, Dietz T, Carpenter SR et al. (2007b) Complexity of coupled human and natural systems. Science 317: $1513-1516$.

Liu J, Hull V, Batistella M et al. (2013) Framing sustainability in a telecoupled world. Ecology and Society 18: 26.

Liu J, Hull V, Luo J et al. (2015) Multiple telecouplings and their complex interrelationships. Ecology and Society 20: 44.

Millennium Ecosystem Assessment (MEA) (2005) Ecosystems and Human Well-Being: Synthesis. Washington, DC: Island Press.

Obst C and Sharma K (2018) The TEEBAgriFood framework: Towards comprehensive evaluation of eco-agrifood systems. TEEB for Agriculture \& Food: Scientific and Economic Foundations, UN Environment, Geneva, pp. 203-245.

Pascual U, Balvanera P, Díaz S et al. (2017) Valuing nature's contributions to people: The IPBES approach. Current Opinion in Environmental Sustainability 26: 7-16.

Power AG (2010) Ecosystem services and agriculture: Tradeoffs and synergies. Philosophical Transactions of the Royal Society B 365: 2959-2971.

Sandhu H, Gemmill-Herren B, de Blaeij A et al. (2018) Application of the TEEBAgriFood framework: Case studies for decision-makers. TEEB for Agriculture \& Food: Scientific and Economic Foundations Report, UN Environment, Geneva, pp. 292-325.

Sandhu H, Müller A and Sukhdev P (2019) Transformation of agriculture and food systems: Application of TEEBAgriFood framework. Solutions 10: 73-79.

Sandhu H, Wratten S, Porter J et al. (2016) Mainstreaming ecosystem services into future farming. Solutions 7: $40-47$.

Sukhdev P (2018) Smarter metrics will help fix our food system. Nature 558: 7.

Swinton SM, Lupi F, Robertson GP et al. (2007) Ecosystem services and agriculture: Cultivating agricultural ecosystems for diverse benefits. Ecological Economics 64: 245-252.

The Economics of Ecosystems and Biodiversity (TEEB) (2008) The Economics of Ecosystem \& Biodiversity: An Interim Report. Cambridge: A Banson Production.

The Economics of Ecosystems and Biodiversity (TEEB) (2015) TEEB for Agriculture \& Food: An Interim Report. Geneva: United Nations Environment Programme. Available at: http://www.teebweb.org/agriculture-and-food/interim-report/ 
The Economics of Ecosystems and Biodiversity (TEEB) (2018) TEEB for Agriculture \& Food: Scientific and Economic Foundations. Geneva: United Nations Environment. Available at: http://teebweb.org/ agrifood/scientific-and-economic-foundations-report/

Tilman D and Clark M (2014) Global diets link environmental sustainability and human health. Nature 515: $518-522$.

Trasande L, Zoeller RT, Hass U et al. (2015) Estimating burden and disease costs of exposure to endocrinedisrupting chemicals in the European union. The Journal of Clinical Endocrinology and Metabolism 100: $1245-1255$.

UNEP (2016) Food Systems and Natural Resources. A Report of the Working Group on Food Systems of the International Resource Panel (H Westhoek, J Ingram, S Van Berkum et al.). Available at: http://www. resourcepanel.org/reports/food-systems-and-natural-resources

United Nations (UN) (2015) Transforming Our World: The 2030 Agenda for Sustainable Development. UN. Available at: https://sustainabledevelopment.un.org/post2015/transformingourworld

Von Braun J, Gerber N, Mirzabaev A et al. (2013) The economics of land degradation. ZEF Working Paper No. 109. Available at: https://ssrn.com/abstract=2237977

World Bank (2006) Where Is the Wealth of Nations - Measuring Capital for the 21st Century. Washington, DC: World Bank.

Zhang W, Ricketts TH, Kremen C et al. (2007) Ecosystem services and dis-services to agriculture. Ecological Economics 64: 253-260. 